\title{
Analysis of Temperature-Promoted and Solvent-Assisted Cross-Linking in Sulfonated Poly(ether ether ketone) (SPEEK) Proton-Conducting Membranes
}

\author{
M. Luisa Di Vona, ${ }^{*}{ }^{\dagger}$ Emanuela Sgreccia, ${ }^{\dagger, \dagger}$ Silvia Licoccia, ${ }^{\dagger}$ Giulio Alberti, ${ }^{\S}$ Laurence Tortet, ${ }^{\dagger}$ \\ and Philippe Knauth \\ Dipartimento di Scienze e Tecnologie Chimiche, Università di Roma "Tor Vergata”, Roma, Italy, Dipartimento \\ di Chimica, Università di Perugia, Via Elce di Sotto 8, Perugia, Italy, and Université de Provence-CNRS: \\ Laboratoire Chimie Provence (UMR 6264), Centre St Jérôme, Marseille, France
}

Received: January 22, 2009; Revised Manuscript Received: March 21, 2009

\begin{abstract}
Sulfonated poly(ether ether ketone) (SPEEK) membranes were thermally treated at temperatures between 120 and $160{ }^{\circ} \mathrm{C}$. Water uptake measured at different relative humidity values or by full immersion in water between 25 and $145^{\circ} \mathrm{C}$ was found to depend very strongly on previous thermal treatment and casting solvent. Water-uptake coefficient values as low as $10-15$ even upon immersion in water at $100{ }^{\circ} \mathrm{C}$ were obtained with membranes treated at $160{ }^{\circ} \mathrm{C}$. This effect is related to cross-linking by $\mathrm{SO}_{2}$ bridges between macromolecular chains. An important role is also played by the casting solvent: among the investigated solvents, dimethylsulfoxide (DMSO) gave the best results. A chemical kinetics model is outlined that permits the estimation of the relevant kinetic parameters, especially the activation energy of the cross-linking reaction, which was found to be about $60 \mathrm{~kJ} / \mathrm{mol}$. These results are of significant importance for the improvement of proton-exchange membrane fuel cells.
\end{abstract}

\section{Introduction}

The current trend toward environmentally friendlier and more efficient power production has shifted the bias from conventional fuels and internal combustion engines toward alternative fuels and power sources. Much interest is focused on developing proton-exchange membrane fuel cells (PEMFCs), which use a polymer membrane as the electrolyte. The future application of this type of technology depends greatly on the enhancement of membrane stability. The polymer electrolyte membrane must be improved in terms of durability; most importantly, it must be compatible with operation at temperatures of around $130{ }^{\circ} \mathrm{C}$ (intermediate temperature) at low relative humidity $(\mathrm{RH})$ for $\mathrm{H}_{2}$ fuel cells, and it must present a reduced fuel crossover for direct methanol fuel cells (DMFCs). ${ }^{1,2}$ The objective is to reduce membrane swelling at high relative humidity and, in the framework of intermediate-temperature fuel cells, to reduce the degradation of properties observed during fuel cell operation at higher temperature.,

Proton-conducting polymers are typically phase-separated into a percolating network of hydrophilic nanopores embedded in a hydrophobic polymer-rich phase domain. ${ }^{5}$ The hydrophilic nanopores contain the acidic moieties that ensure proton conductivity; the hydrophobic phase domain provides mechanical strength. ${ }^{6,7}$ Whereas water sorption improves the proton conductivity, it also leads to morphological instability and, at elevated water content, to membrane swelling. ${ }^{8}$

It is known that the exposure of organic matrixes to humidity is the main cause of the loss of membrane mechanical strength, determined especially by the plasticizing effect of water. ${ }^{9,10}$ This effect is dramatic at high temperature and limits the maximum working temperature of the currently used perfluorinated

* Address correspondence to Dr. M. Luisa Di Vona. Tel.: +3906 72594385. Fax: +3906 72594328. E-mail: divona@uniroma2.it.

†Università di Roma "Tor Vergata".

* Université de Provence.

$\S$ Università di Perugia. membranes to $80-90{ }^{\circ} \mathrm{C} .{ }^{11}$ However, it is desirable to operate at temperatures above $80{ }^{\circ} \mathrm{C}$, in the range of $120-140{ }^{\circ} \mathrm{C}$, to enhance the conductivity of membranes; to reduce anode poisoning due to adsorbed $\mathrm{CO}$, which is present as fuel impurity; and to improve the fuel oxidation kinetics, leading to an enhancement of fuel cell efficiency. ${ }^{12}$ Furthermore, higher working temperatures reduce heat-exchanger requirements, allowing smaller radiator systems in electric cars. ${ }^{13,14}$

Sulfonated aromatic polymers (SAPs) are promising alternative membrane materials. The most important examples are the poly(ether ether ketone) (PEEK) and poly(phenyl sulfone) (PPSU) polymer families, which are very well-known hightemperature engineering resins. ${ }^{15,16}$ Their unique combination of chemical and physical properties, such as high hydrolytic, thermal, and oxidation stabilities; low inflammability; and excellent mechanical properties, are combined with low cost and easy processability. ${ }^{17}$ For applications as fuel cell membranes, these polymers are usually sulfonated with high degrees of sulfonation, required for appropriate proton conductivity. ${ }^{18}$ However, this lowers the mechanical and morphological properties and leads to highly swellable or even water-soluble products. ${ }^{19-21}$ Great efforts have been made to reduce swelling and improve performance. ${ }^{22}$ To this end, a carefully designed synthesis should be carried out, modulating the requested properties, especially regarding the separation between hydrophilic and hydrophobic domains. ${ }^{5,23}$ The goal is to achieve a locally high density of functional groups such as sulfonic acid groups but to keep the swelling low by appropriate cross-linking and/or use of hybrid membranes. ${ }^{24-26}$

Another strategy is the application of appropriate thermal treatments. Annealing is a well-known concept in metallurgy and ceramics and a thousands-of-years-old technique. However, it is rarely systematically applied to polymers, especially polymer electrolyte membranes. Recently, it was shown that the loss of performance of Nafion, the most-used perfluorinated membrane, is related to morphology changes of the polymer 


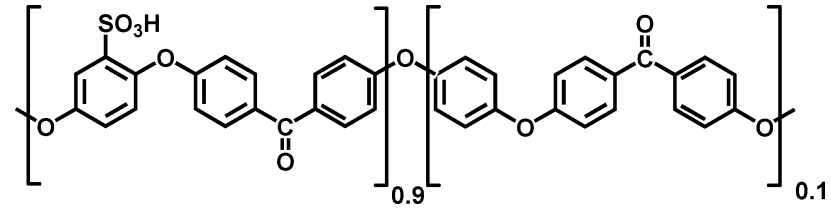

Figure 1. Repeat unit of SPEEK with DS $=0.9$.

and that the magnitude of these changes is, in turn, related to the treatments previously performed on the membrane. ${ }^{27} \mathrm{~A}$ kinetic investigation of the water uptake of Nafion after different hydrothermal and thermal treatments suggested that the kinetics of water uptake is the result of two distinct processes: a very fast process attributed to the time of osmotic equilibration within the thin membrane and a second, very slow process associated with a slow modification of the Nafion conformation with temperature. The irreversibility of the hydration process with temperature was related to the irreversibility of these conformational changes. The memory of the thermal treatment is due to the fact that ionomers are essentially constituted of an amorphous matrix in which some nanocrystalline phases are embedded. ${ }^{27}$ It has been clarified that significant discrepancies between membrane properties observed in the literature can be traced to the out-of-equilibrium state of the largely amorphous polymers and that such discrepancies depend on the membrane history, for example, in terms of thermal treatments. It has also been suggested that there is an elementary correlation between the water uptake of membranes (and thus their electrochemical properties during fuel cell operation) and their mechanical properties, especially the elastic modulus, where higher water uptake is related to lower tensile strength of the polymer matrix. ${ }^{27}$

The aim of the present work was to explore whether it is possible to enhance the performance of sulfonated poly(ether ether ketone) (SPEEK) in a simple and economical way by appropriate thermal "curing" treatments between 120 and 160 ${ }^{\circ} \mathrm{C}$. Only a few examples of thermal treatments applied to proton-conducting polymer membranes have been reported in the literature. ${ }^{28-31}$ In addition, the mechanism of membrane modification was explored, and a chemical kinetics model proposed.

\section{Experimental Section}

Synthesis and Thermal Treatment of Ionomer Membranes. Sulfonated poly(ether ether ketone) (SPEEK) was prepared by the reaction of PEEK (Victrex 450P, MW = 38300) with concentrated sulfuric acid at $50{ }^{\circ} \mathrm{C}$ for times between 3 and 5 days, depending on the desired degree of sulfonation. The solution was poured under continuous stirring into a large excess of ice-cold water. After being allowed to stand overnight, the white precipitate was filtered and washed several times with cold water to neutral $\mathrm{pH}$. The sulfonated polymer (SPEEK) was then dried at $80^{\circ} \mathrm{C}$ for 1 night. The degree of sulfonation (DS) was evaluated both by ${ }^{1} \mathrm{H}$ NMR spectroscopy ${ }^{32}$ and by titration with the following results: DS values between 0.6 and 0.9 were obtained depending on the reaction time.

The procedure for membrane preparation was solution casting using dimethylsulfoxide (DMSO) and dimethylacetamide (DMAc) as solvents. In a typical experiment, a 250-mg sample was dissolved in $30 \mathrm{~mL}$ of solvent. The resulting mixture was stirred for $4 \mathrm{~h}$, evaporated to $5 \mathrm{~mL}$, cast onto a Petri dish, and heated to dryness for $12 \mathrm{~h}$ at $80{ }^{\circ} \mathrm{C}$. After being allowed to cool to room temperature, the resulting membranes (called "standard samples" in the following discussion) were peeled off and treated under dynamic vacuum for $24 \mathrm{~h}$ at $80{ }^{\circ} \mathrm{C}$ for solvent removal. However, a small amount of DMSO remained in the membranes after this step.

Subsequent thermal treatments of SAP membranes were performed at temperatures between 120 and $160{ }^{\circ} \mathrm{C}$, which were chosen after preliminary measurements. Three types of curing were performed: (i) $64 \mathrm{~h}$ at 120 or $160{ }^{\circ} \mathrm{C}$, (ii) $168 \mathrm{~h}$ at $120^{\circ} \mathrm{C}$, and (iii) $64 \mathrm{~h}$ at $120^{\circ} \mathrm{C}$ followed by $64 \mathrm{~h}$ at $160{ }^{\circ} \mathrm{C}$ (yielding "double-treated" samples).

To study the effect of the casting solvent, membranes of SPEEK 0.7 were also prepared using $N$-methylpyrrolidone (NMP) and acetone/water (5:1) mixtures and were doubletreated.

Thermal Reaction of $\boldsymbol{p}$-Toluenesulfonic Acid. $p$-Toluenesulfonic acid (pTSA, Aldrich, 99.8\%) was thermally treated in the presence of a small amount of DMSO [pTSA/DMSO = 10:1 (w/w)] under conditions similar to those applied to the polymer membranes, specifically, $64 \mathrm{~h}$ at $120{ }^{\circ} \mathrm{C}$ followed by $64 \mathrm{~h}$ at $160{ }^{\circ} \mathrm{C}$. The products, dissolved in DMSO, were analyzed by ${ }^{1} \mathrm{H}$ NMR spectroscopy and gas chromatographymass spectrometry.

Structural Characterization. ${ }^{1} \mathrm{H}$ and ${ }^{13} \mathrm{C}$ nuclear magnetic resonance spectra were recorded with a Bruker Avance 400 spectrometer operating at 400.13 and $100.56 \mathrm{MHz}$, respectively. The samples were dissolved in $d_{6}$-DMSO or DMAc. In the latter case, the spectra were recorded using $\mathrm{D}_{2} \mathrm{O}$ as the external lock. Chemical shifts (ppm) are referenced to tetramethylsilane (TMS).

FTIR spectra of membrane samples heated to different temperatures were collected in transmission mode in the range of $4000-400 \mathrm{~cm}^{-1}$ (32 scans, $2 \mathrm{~cm}^{-1}$ resolution) with a Bruker Equinox 55. The membrane thickness was ca. $60 \mu \mathrm{m}$ in all cases. A background spectrum was run, and sample spectra were normalized against the background spectrum.

X-ray diffraction (XRD) patterns were recorded with a Siemens D5000 diffractometer using $\mathrm{Cu} \mathrm{K \alpha}$ radiation $(\lambda=$ $0.1540 \mathrm{~nm}$ ), steps of $0.04^{\circ}$, and a 1 -s step time.

Carbon atomic charges were calculated by Mulliken population analysis (MPA) on the optimized geometry obtained by semiempirical methods (AM1). Geometric optimization was terminated when the energy difference between successive iterations was lower than $4.2 \mathrm{~J} / \mathrm{mol}$. Starting from the AM1 geometry, single-point ab initio calculations with the $6-31 \mathrm{G}^{*}$ basis set were performed using the Gaussian system of programs. ${ }^{33}$

The elemental analysis was performed on two samples: SPEEK DS $=0.6$ treated at $120{ }^{\circ} \mathrm{C}$ for $64 \mathrm{~h}$ and SPEEK DS $=$ 0.6 double-treated.

Water Uptake of Membranes in Liquid Water in the Temperature Range $\mathbf{2 5}-145{ }^{\circ} \mathrm{C}$. The anhydrous samples were first dried in situ $\left(3 \mathrm{~h}\right.$ at $80{ }^{\circ} \mathrm{C}$ under $\left.0 \% \mathrm{RH}\right)$, weighed, and immersed in deionized water contained in Teflon vessels of suitable thickness, as reported in ref 27. The vessels were hermetically closed and placed inside a temperature-controlled oven. Immersion times were between 6 days at $25^{\circ} \mathrm{C}$ and $1 \mathrm{~h}$ at $145^{\circ} \mathrm{C}$ until constant water-uptake values were reached. After the treatments, the vessels were cooled to room temperature, the samples were recovered, and the excess external liquid water was removed by filter paper. The samples were immediately placed in a closed glass container and weighed.

Water Vapor Sorption Isotherms at $25^{\circ} \mathrm{C}$. By equilibration with water vapor at $25^{\circ} \mathrm{C}$ under $0-95 \% \mathrm{RH}$, the water sorption isotherms were recorded using a TA5000 thermogravimetric analyzer. RH was modified in $5 \%$ or $10 \%$ steps, and the water 


\section{SCHEME 1}<smiles>COc1ccc(Oc2ccc(C(=O)c3ccc(C)cc3)cc2)c(Oc2ccc(OS(=O)(=O)O)cc2Oc2ccc(C(=O)c3ccc(C)cc3)cc2)c1</smiles><smiles></smiles><smiles>COc1ccc(OS(=O)(=O)c2cc(OC)ccc2OC)c(OC)c1</smiles><smiles>COc1ccc(Oc2ccc(C(=O)c3ccc(C)cc3)cc2)c([S+](=O)[O-])c1</smiles><smiles>COc1ccc(Oc2ccc(C(=O)c3ccc(C)cc3)cc2)c(S(=O)(=O)C2(Sc3ccc(OC)c(S(=O)(=O)O)c3)C=CC(C(=O)c3ccc(C)cc3)=CC2)c1</smiles><smiles>COC1=CC(CO)=C(Oc2ccc(C(=O)c3ccc(C)cc3)cc2)C(C)C1</smiles><smiles>COc1ccc(Oc2ccc(C(=O)c3ccc(C)cc3)cc2)c(S(=O)(=O)C2(Oc3ccc(OC)c(S(=O)(=O)O)c3)C=CC(C(=O)c3ccc(C)cc3)=CC2(O)S(=O)(=O)c2ccc(OC)c(S(=O)(=O)O)c2)c1</smiles>
$\mathrm{SO}_{2}$<smiles>COc1cc(OS(=O)(=O)c2cc(OC)ccc2OC)c(OC)c(S(=O)(=O)O)c1</smiles>

D

uptake recorded at each step for $2 \mathrm{~h}$. Prior to all experiments, the membranes were first dried in situ for $3 \mathrm{~h}$ at $80{ }^{\circ} \mathrm{C}$ under $0 \%$ RH.

High-Resolution Thermogravimetry. The thermal degradation of the polymer membranes was investigated by highresolution thermogravimetric analysis (TGA Q500, TA Instruments), performed between 25 and $800{ }^{\circ} \mathrm{C}$ with a maximum heating rate of $5{ }^{\circ} \mathrm{C} / \mathrm{min}$ under air flux in platinum sample holders.
Ion-Exchange-Capacity Measurements. The ion-exchange capacity (IEC, in milliequivalents per gram of dry polymer) was determined by titration using the following procedure: A dry weight of $0.1-0.2 \mathrm{~g}$ of the membrane in the acid form was immersed in $0.098 \mathrm{~N} \mathrm{NaOH}$ solution under stirring at room temperature for $24 \mathrm{~h}$. The mixture was back-titrated with a 0.1 $\mathrm{N} \mathrm{HCl}$ solution. The $\mathrm{pH}$ was recorded potentiometrically to determine the equivalence point. ${ }^{32}$

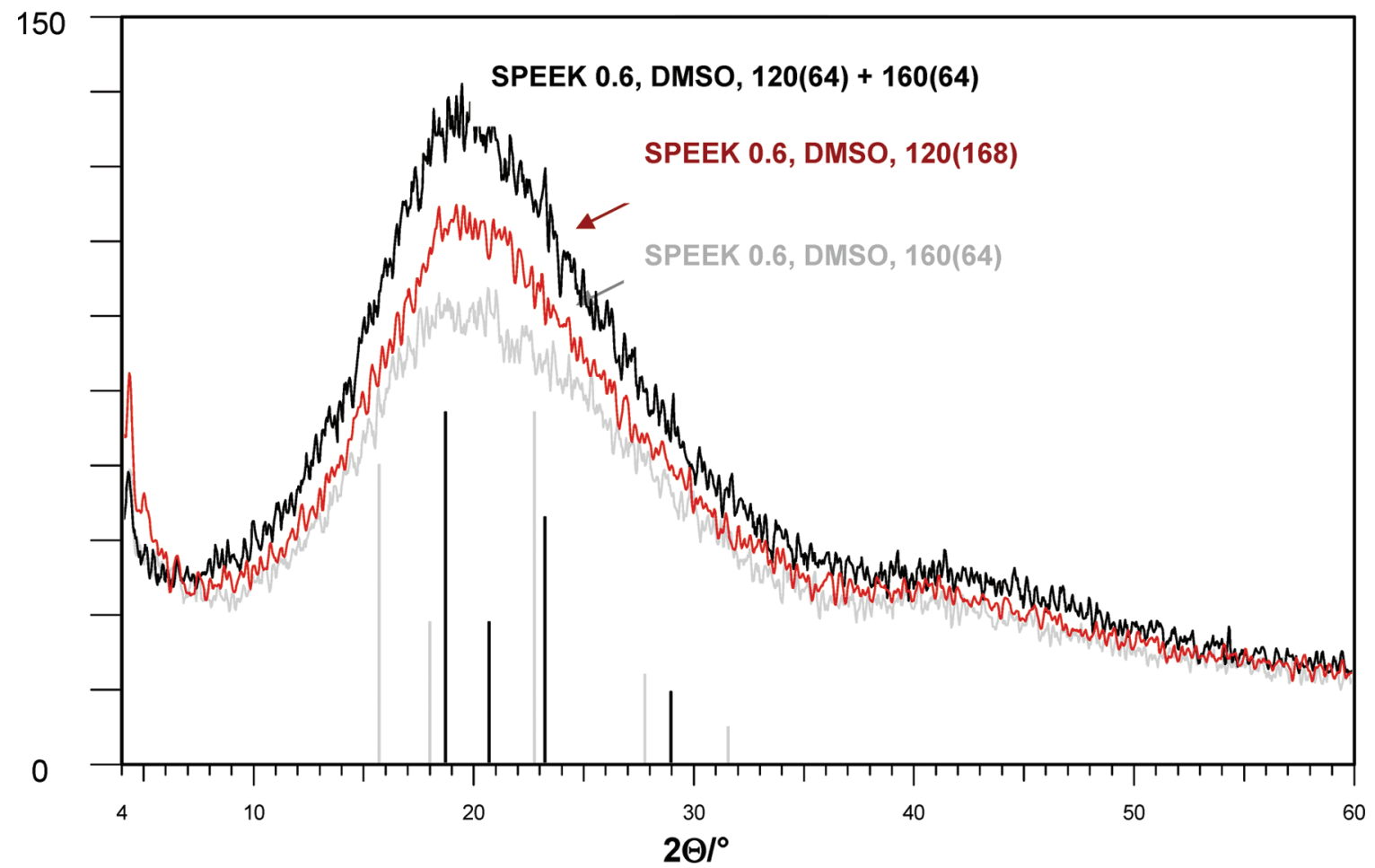

Figure 2. XRD patterns of SPEEK membranes treated at different temperatures (JCPDS data files 00-052-2277 and 00-052-2278). 


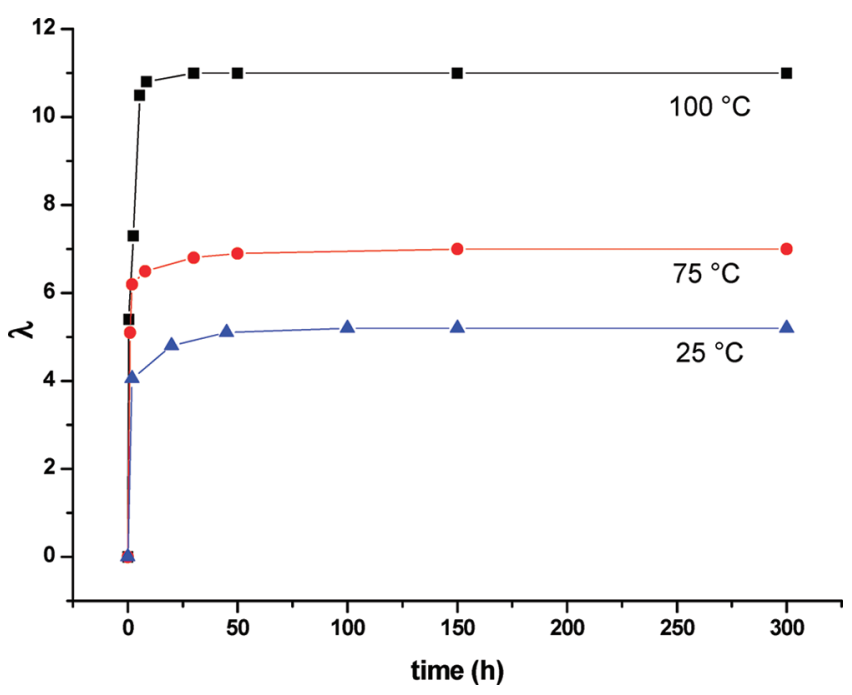

Figure 3. Water-uptake kinetics of SPEEK (DS = 0.6) membranes treated for $64 \mathrm{~h}$ at $160{ }^{\circ} \mathrm{C}$ after immersion in deionized water of different temperatures.

\section{Results}

Figure 1 presents the repeat unit of SPEEK (DS = 0.9). The elemental analysis of SPEEK membranes before and after thermal treatments showed the following results, reproducible over three samples (mass \%): for SPEEK DS $=0.6$ treated at $120{ }^{\circ} \mathrm{C}$ for $64 \mathrm{~h}, \mathrm{C} 60.1$ (60.2), S 7.8 (8.1); for SPEEK DS = 0.6 double-treated, C 64.3 (63.9), S 7.9 (8.2). The values in parentheses were calculated considering a repeat unit containing $0.4 \mathrm{~mol}$ of DMSO and $1.5 \mathrm{~mol}$ of water for the first sample and a repeat unit containing $0.10 \mathrm{~mol}$ of cross-link of type $\mathrm{D}^{\prime}$, $0.05 \mathrm{~mol}$ of cross-link of type C (see Scheme 1), $0.4 \mathrm{~mol}$ of DMSO, and $0.5 \mathrm{~mol}$ of water for the second sample.

The presence of residual solvent, 0.4 molecule of DMSO per macromolecule of SPEEK, plays an important role in the crosslinking reaction, as shown below.

The XRD patterns of SPEEK membranes treated at different temperatures are presented in Figure 2. One notices a fully amorphous structure, regardless of the thermal treatment performed.

The water-uptake kinetics of SPEEK (DS $=0.6$ ) membranes treated for $64 \mathrm{~h}$ at $160{ }^{\circ} \mathrm{C}$ after immersion in deionized water of different temperatures is shown in Figure 3. The water-uptake coefficients, $\lambda$, are defined according to the equation

$$
\lambda=\frac{1000\left(W_{\text {wet }}-W_{\text {dry }}\right)}{18 W_{\text {dry }} \text { IEC }}
$$

where $W_{\text {dry }}$ and $W_{\text {wet }}$ are the masses of the polymer membrane before and after immersion, respectively. Immersion times of several days were necessary to reach a constant water-uptake coefficient at $25^{\circ} \mathrm{C}$, whereas the equilibration was much faster at $100{ }^{\circ} \mathrm{C}$. The long equilibration times are due to slow changes of conformations with the water uptake.

It is noteworthy that, even at $100{ }^{\circ} \mathrm{C}$, the water-uptake coefficient of this thermally treated membrane reached a value of only 11, whereas an untreated membrane dissolved completely.

Figure 4 summarizes water-uptake coefficients obtained in this way as a function of water temperature for SAPs after different thermal treatments and for the two casting solvents DMAc and DMSO. It can be noted that thermal treatments at $120{ }^{\circ} \mathrm{C}$ are less efficient and that SAPs cast from DMAc are less modified by thermal treatments than those cast from DMSO.

Water-uptake coefficients determined after full immersion in water at different temperatures are reported for differently treated

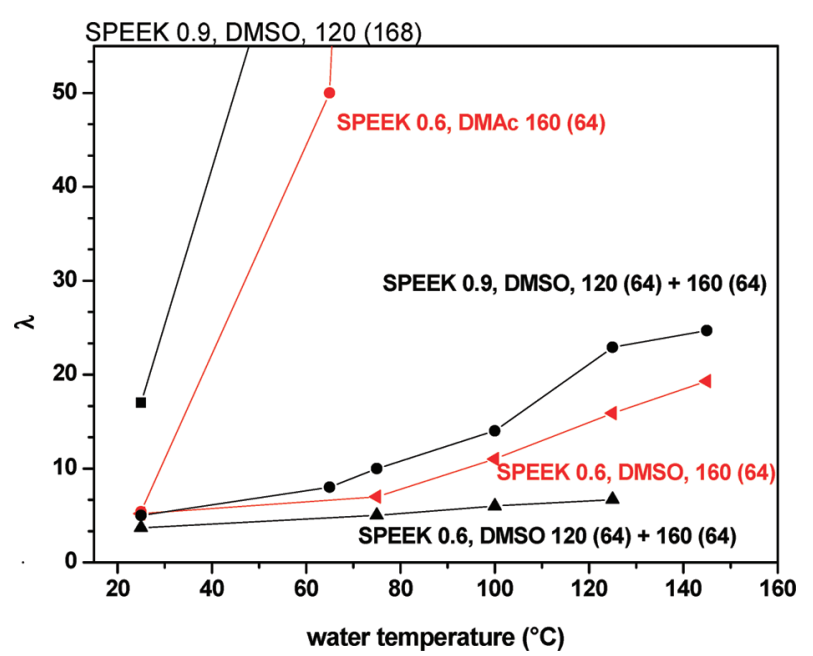

Figure 4. Water-uptake coefficients obtained for immersion as a function of water temperature for SPEEK after different thermal treatments and for the two casting solvents DMAc and DMSO.

TABLE 1: Water-Uptake Coefficients $(\lambda)$ of Membranes Measured by Immersion in Liquid Water at Different Temperatures ${ }^{a}$

\begin{tabular}{lrlllll}
\hline \multirow{2}{*}{$\begin{array}{c}\text { casting solvent, } \\
\text { thermal treatment } \\
\text { temperature (time) })^{b}\end{array}$} & \multicolumn{6}{c}{ water temperature $\left({ }^{\circ} \mathrm{C}\right)$} \\
\cline { 2 - 7 } & SPEEK & 0.6 & 75 & 100 & 125 & 145 \\
\hline DMSO, $120(64)$ & 8.0 & - & $\infty^{c}$ & & & \\
DMSO, $120(168)$ & 7.0 & 20.0 & 124.0 & $\infty$ & & \\
DMAc, $120(168)$ & 5.0 & 83.0 & 556.0 & $\infty$ & & \\
DMSO, $160(64)$ & 5.2 & - & 7.0 & 11.0 & 15.9 & 19.3 \\
DMAc, $160(64)$ & 5.4 & 50.0 & $\infty$ & & & \\
DMSO, $120(64)+160(64)$ & 3.6 & - & 5.0 & 6.0 & 6.7 & - \\
DMAc, $120(64)+160(64)$ & 5.2 & 50.0 & $\infty$ & & & \\
NMP & 8.2 & - & - & $\infty$ & & \\
acetone $+\mathrm{H}_{2} \mathrm{O}$ & 16.0 & - & - & 39.0 & - & - \\
& SPEEK & 0.7 & & & & \\
DMSO, $120(64)$ & 10.0 & - & $\infty$ & & & \\
DMSO, $120(64)+160(64)$ & 3.8 & - & - & 10.0 & - & - \\
& SPEEK 0.9 & & & & \\
DMSO, $120(64)$ & 33.0 & $\infty$ & & & & \\
DMSO, $120(168)$ & 17.0 & $\infty$ & & & & \\
DMSO, $160(64)$ & 6.2 & - & - & 16.1 & - & 27.3 \\
DMSO, $120(64)+160(64)$ & 5.0 & 8.0 & 10.0 & 14.0 & 22.9 & 24.7
\end{tabular}

${ }^{a} \lambda$ calculated using eq 1 and the nominal IEC. ${ }^{b}$ Thermal treatment temperature in ${ }^{\circ} \mathrm{C}$ and time in hours. ${ }^{c} \infty$ means that the membranes completely dissolved.

SAPs in Table 1. The significant impact of the heat treatments is immediately apparent. The coefficients $\lambda$ remain at reasonable values even up to water temperatures of $145^{\circ} \mathrm{C}$, for membranes cast from DMSO and heated to $160{ }^{\circ} \mathrm{C}$.

Water vapor sorption isotherms are presented for different membranes in Figure 5. The water-uptake values are consistent with those obtained by immersion in liquid water. The sorption isotherms confirm that the double treatment is more efficient in reducing the amount of sorbed water (Figure 5a).

The membranes were analyzed by FTIR spectroscopy in order to characterize macromolecular changes occurring during thermal treatments. A typical spectrum of a SPEEK 0.9 sample heated to $160{ }^{\circ} \mathrm{C}$ is reported in Figure $6 \mathrm{a}$ (red line) and compared with the spectrum of an unheated SPEEK 0.9 sample (blue line). PEEK absorption is evident in both spectra. ${ }^{34,35}$ Subtraction of the normalized spectrum of untreated SPEEK from that of 160 ${ }^{\circ} \mathrm{C}$ treated SPEEK is shown in Figure $6 \mathrm{~b}$ to evidence the 

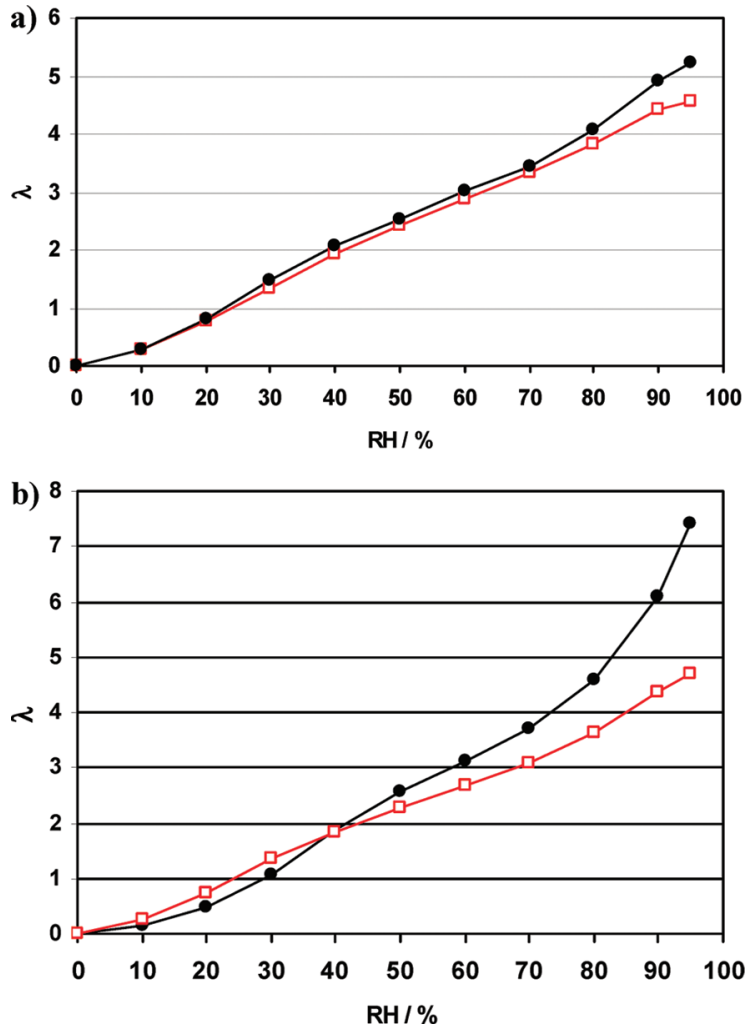

Figure 5. Water sorption isotherms at $25{ }^{\circ} \mathrm{C}$ for (a) SPEEK 0.6 in DMSO $(\bullet)$ treated at $120^{\circ} \mathrm{C}(168 \mathrm{~h})$ and $(\square)$ treated at $160{ }^{\circ} \mathrm{C}(64 \mathrm{~h})$ and (b) SPEEK 0.9 in DMSO $(\bullet)$ treated at $120^{\circ} \mathrm{C}(168 \mathrm{~h})$ and $(\square)$ double-treated.
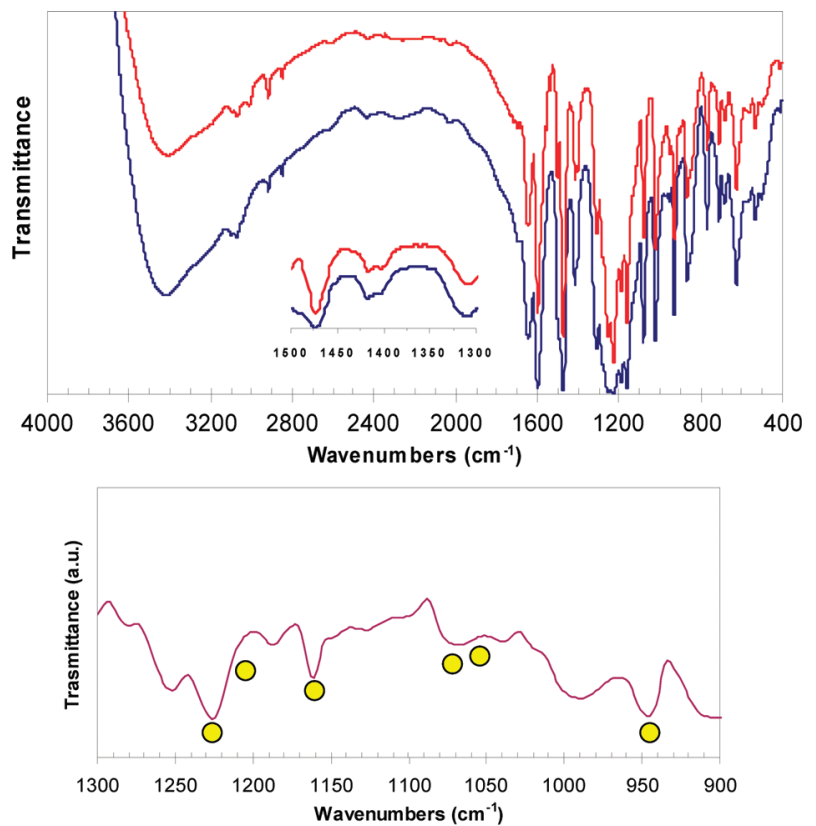

Figure 6. FTIR spectra of (a) SPEEK 0.9, DMSO, standard sample (blue line), and SPEEK 0.9, DMSO, $160{ }^{\circ} \mathrm{C}(64 \mathrm{~h})$ (red line). (b) Difference spectrum [(red line) - 1(blue line)].

absorption characteristics of the sample heated to $160{ }^{\circ} \mathrm{C}$ (yellow circles). Signals due to 1:2:4-substituted phenyl rings are present at 1225 and $1080 \mathrm{~cm}^{-1}$. It is also possible to observe bands of aromatic sulfone moieties at $1210 \mathrm{~cm}^{-1}$ (shoulder) and 1065 $\mathrm{cm}^{-1}$ (tail). The $\mathrm{S}=\mathrm{O}$ stretching vibration of $\mathrm{PhSO}_{2} \mathrm{Ph}$ is present at $1165 \mathrm{~cm}^{-1} \cdot 36,37$ These results indicate that sulfone cross-links are formed between macromolecular chains. ${ }^{38}$ Simple condensation products, for example, by $-\mathrm{S}-\mathrm{O}-\mathrm{S}-$ bonds, which have
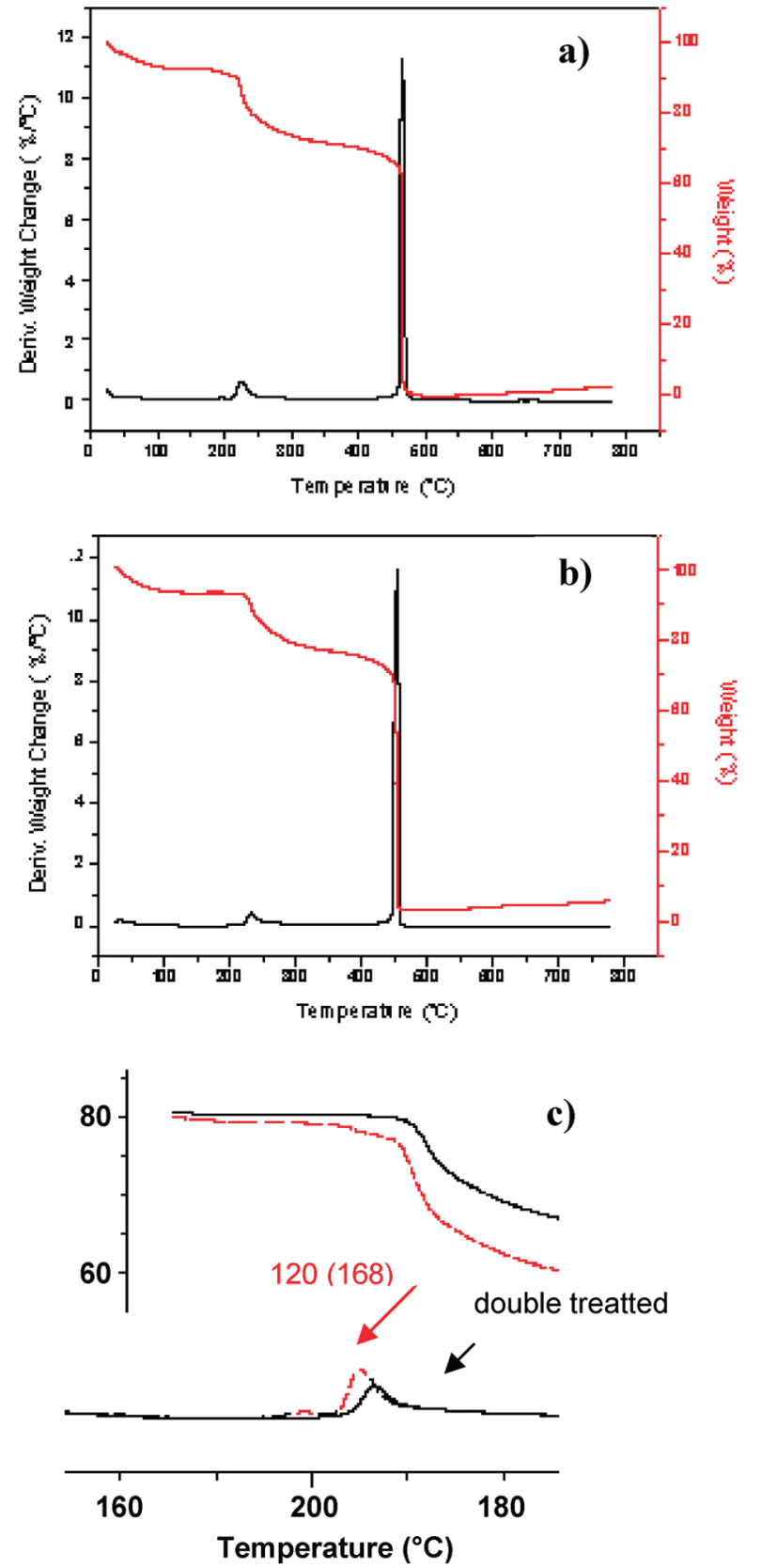

Figure 7. TGA/DTG curves for (a) SPEEK 0.9, DMSO, $120{ }^{\circ} \mathrm{C}(168$ h), and (b) SPEEK 0.9, DMSO, double-treated. (c) Comparison of a and $\mathrm{b}$.

been reported in annealed ionomers ${ }^{39}$ and absorb around 1450 $\mathrm{cm}^{-1}$, were not observed here, as shown in the inset spectrum in Figure 6a.

Typical thermogravimetric curves measured on two differently thermally treated SPEEK (DS $=0.9$ ) membranes are shown in Figure 7. After an initial mass loss below $100{ }^{\circ} \mathrm{C}$ due to water evaporation, the mass loss around $250{ }^{\circ} \mathrm{C}$ is attributable to loss of sulfonate groups, as can be deduced from FTIR measurements and as was shown in previous investigations. ${ }^{38,40}$ This mass loss is clearly reduced for double-treated membranes (Figure 7c). From the peak area under the signal, a modified degree of sulfonation can be calculated. The values calculated from such thermogravimetric experiments are reported for different membranes in Table 2. Table 2 also lists titration results expressed in terms of ion-exchange capacity (IEC in mequiv/ g) for membranes heated to different temperatures. According to thermal analysis and IEC titration, which are in very good 
TABLE 2: Thermogravimetric Analysis (TGA), Titration, and Elemental Analysis of SPEEK Membranes

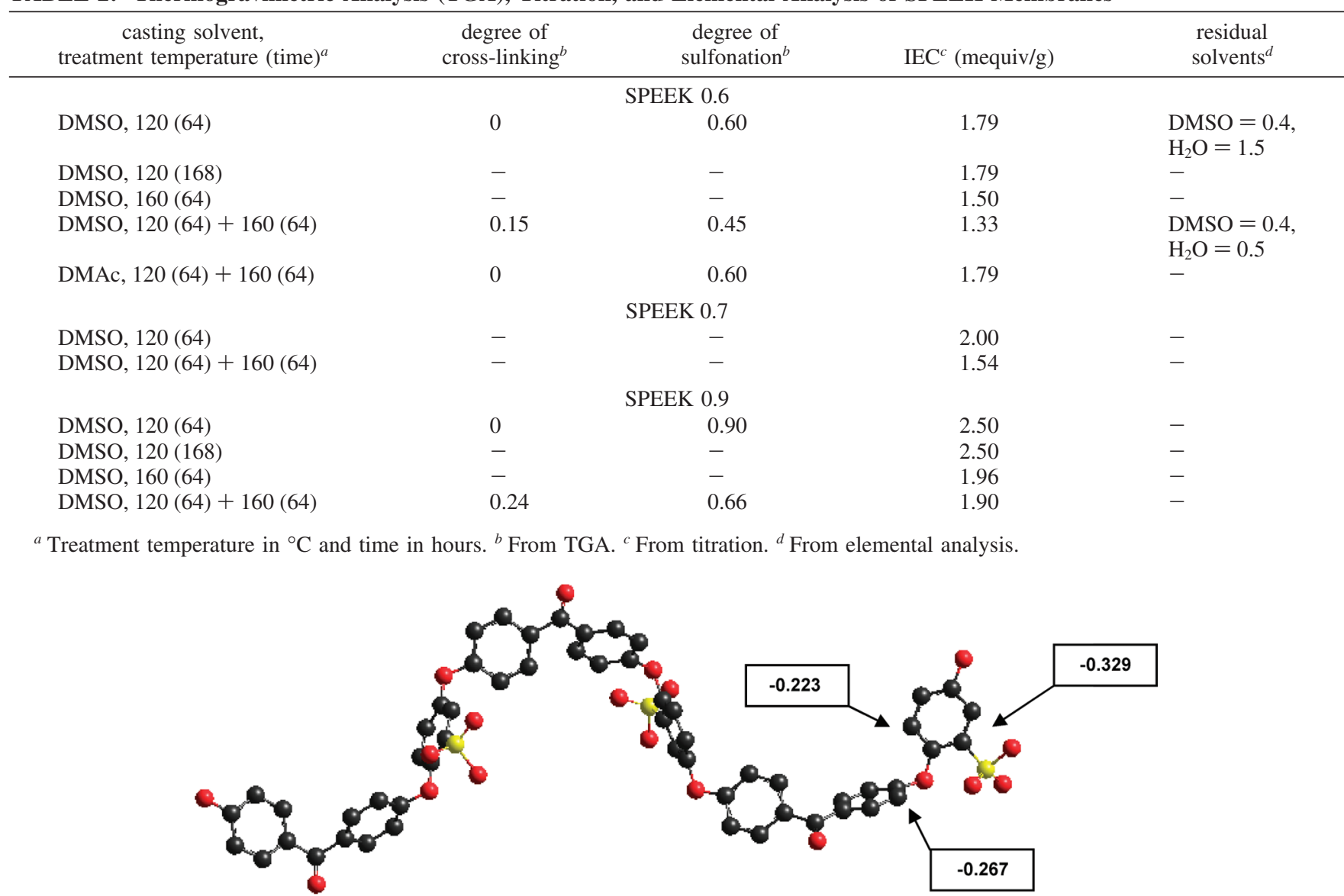

Figure 8. Calculated optimal conformation of SPEEK. Hydrogen atoms are omitted for the sake of clarity.

agreement (Table 2), about $30 \%$ of the sulfonate groups were lost upon thermal treatment at $160{ }^{\circ} \mathrm{C}$. The final decomposition of the polymer membrane was observed above $450{ }^{\circ} \mathrm{C}$, in agreement with the excellent thermal stability of fully aromatic polymers. Cross-linking $\mathrm{SO}_{2}$ bridges decomposed together with the main polymer chains, as in the case of poly(phenyl sulfone) or other sulfone-containing polymers. ${ }^{41}$

\section{Discussion}

In principle, changes in the water uptake of ionomer membranes can be related to different causes such as changes of their conformation and/or degree of crystallinity and/or elimination of previous permanent deformations (memory) provoked by water uptake at high temperature. ${ }^{27}$ XRD patterns rule out significant changes of polymer crystallinity. The dramatic reduction in water uptake observed in this investigation, which stabilizes ionomers at a high degree of sulfonation even at temperatures as high as $145{ }^{\circ} \mathrm{C}$, cannot be due to the mentioned reasons, and the only reasonable explanation is the formation of covalent bonds between adjacent polymeric chains, in agreement with FTIR spectra.

Thermal Treatment Effect. NMR spectra of SPEEK samples show that thermal treatments at $120{ }^{\circ} \mathrm{C}$ do not induce any structural changes. Thermogravimetry, FTIR, and water-uptake data indicate that cross-linking occurs when the temperature of the thermal treatment is higher than $120^{\circ} \mathrm{C}$ for membranes cast in DMSO. Scheme 1 shows the possible pathways for the formation of a sulfone linkage. The formation of the bridges occurs by an electrophilic aromatic substitution $\left(\mathrm{S}_{\mathrm{E}} \mathrm{Ar}\right)$ with a Friedel-Crafts type acylation mechanism via a Wheland intermediate. ${ }^{42}$ In principle, two routes can be followed: route $\mathrm{a}$, ipso substitution ${ }^{30}$ or route $\mathrm{b}, \mathrm{H}$ substitution. In route $\mathrm{b}$, the two rings where the electrophilic attack occurs are deactivated, and consequently, two products are expected to be formed: D and $\mathrm{D}^{\prime}$. From Scheme 1, it is clear that route a consumes more sulfonic groups, because it involves the loss of $\mathrm{SO}_{2}$ moieties. A clear NMR analysis of the products obtained by curing DMSO-SPEEK above $120{ }^{\circ} \mathrm{C}$ is not possible, because the thermally treated membranes are insoluble in any typical solvent. The results of elemental analysis are also not unequivocal, given the very similar molecular weights of the different compounds.

The electrophilic reaction preferentially occurs on the carbon atom having the more negative charge density; thus, to ascertain whether there was a favored product, a theoretical approach based on ab initio calculations was used to determine the carbon atomic charges. ${ }^{43}$ The chosen model was SPEEK with three repeat units. Figure 8 indicates the $\mathrm{C}$-atom charges calculated by Mulliken population analysis (MPA). The lowest densities are located on the carbon atom in the benzophenonic ring (product $\mathrm{D}^{\prime}$, route $\mathrm{b}$ ) and on the carbon atom linked to the sulfonic group (route a). Furthermore, in the case of $p$ toluenesulfonic acid, chosen as a model compound and subjected to similar thermal treatments, a $20 \%$ conversion was obtained with two products in a 4:1 ratio (Scheme 2). Combining all of these pieces of information, it is reasonable to assume that we obtained as the main product the cross-linked polymer $\mathrm{D}^{\prime}$ and as the secondary product $\mathrm{C}$.

Cross-Linking Kinetics Model. Based on the previous discussion, considering polymer $\mathrm{D}^{\prime}$ as the only product (see 


\section{SCHEME 2}

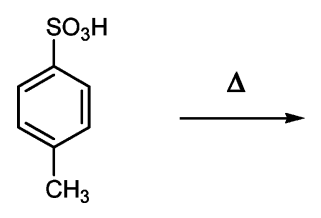

$$
\ln (\mathrm{IEC})=\ln \left(\mathrm{IEC}^{\circ}\right)-2 \mathrm{Ke}^{-E_{\mathrm{A}} / R T} t
$$

In this equation, $\operatorname{IEC}^{\circ}$ is the ion-exchange capacity of a SPEEK membrane before any thermal treatment (corresponding to $t=$ 0 in the integration).

Figure 9 shows resulting plots of $\ln \left(\right.$ IEC) $\mathrm{vs}^{-\left(E_{\mathrm{A}} / R T\right)} t$ for SPEEK membranes (DS $=0.6,0.7$, and 0.9), cast from DMSO. Here, $T$ and $t$ are the temperature and the time, respectively, of the thermal treatment of the membrane. (For double-treated samples, the terms are added.) Linear relations are indeed observed in all cases (Figure 9). The good correlation obtained using a first-order kinetic expression justifies the assumption that the reaction rate depends only on the concentration of sulfonic acid groups. The quality of the linear plot is very sensitive to the activation energy value used for calculation. The determined value, $(60 \pm 10) \mathrm{kJ} / \mathrm{mol}$, is in good agreement with those reported in the literature for the sulfonation reaction performed on PEEK. ${ }^{45}$ The calculated intercepts, which should be equivalent to the ionexchange coefficients of uncured membranes, are indeed consistent with the experimental results (Table 1).

Altogether, these data are completely consistent with the model of a cross-linking reaction occurring between SAP chains during curing at temperatures above $120^{\circ} \mathrm{C}$, which strongly modifies the water-uptake behavior of the membranes.

Role of the Casting Solvent. The presence of residual solvent, 0.4 molecule of DMSO per macromolecule of SPEEK, plays an important role in the cross-linking reaction. In contrast to membranes cast in DMSO, DMAc-cast samples treated above $120{ }^{\circ} \mathrm{C}$ were found to be very soluble in many solvents, such as $d_{6}$-DMSO. NMR spectra recorded on double-treated DMAccast membranes showed a constant DS after the thermal treatment, indicating the absence of a cross-linking reaction. The IEC obtained by titration confirmed this result.

In a recent article, Kaliaguine et al. ${ }^{46}$ reported that the thermal cross-linking of SPEEK does not occur if no cross-linkers, such as polyatomic alcohols, have been added. In these experiments, the membranes were prepared using different casting solvents, but not DMSO. The results of our experiments confirm that no crosslinking occurs in membranes cast from DMAc and NMP. The samples prepared in aqueous solvents (acetone/water) had an intermediate behavior. Excluding a direct participation of DMSO in the reaction (cf. FTIR spectroscopy and the pTSA reaction), the role of the casting solvent can be understood considering its acidity constant. In basic solvents (such as DMAc and NMP), the formation of an acid-base complex between the basic center of the solvent and the sulfonic acid groups prevents the cross-linking reaction. In aqueous media, such as aqueous acetone, the presence of water causes the dissociation of the sulfonic groups, thereby limiting the formation of the electrophilic species (leveling effect

The cross-linking reaction can be considered a first-order reaction. The rate constant $k_{1}$ can be expressed using the Arrhenius equation

$$
v=-\frac{\mathrm{d}[\mathrm{A}]}{\mathrm{d} t}=2[\mathrm{~A}] K \mathrm{e}^{-E_{\mathrm{A}} / R T}
$$

In this equation, $v$ is the cross-linking reaction rate, $K$ is the kinetic prefactor, $R$ is the gas constant, $T$ is the absolute temperature, and $E_{\mathrm{A}}$ is the activation energy of the reaction. [A] is the concentration of unreacted SPEEK, that is, of sulfonate groups, which decreases during the cross-linking reaction. The concentration of sulfonic acid groups in SAPs is proportional to the ion-exchange coefficient, determined by titration. [A] can therefore be replaced by the IEC, which can be used for monitoring the reaction rate. Using eq 10 , one obtains easily the relation:

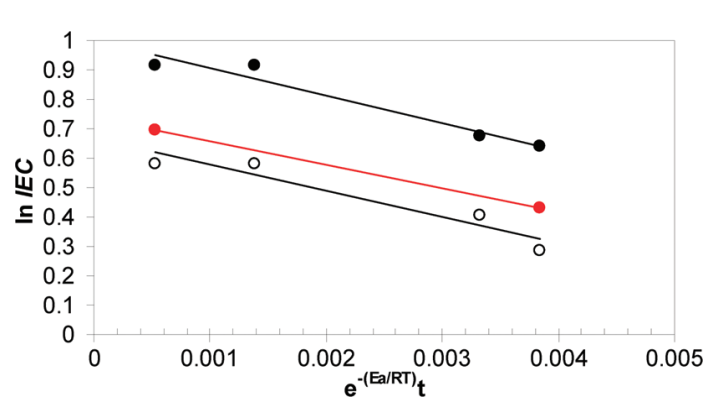

Figure 9. Plots according to eq 11: SPEEK 0.9 (black solid circles), SPEEK 0.7 (red solid circles), and SPEEK 0.6 (open circles) membranes cast from DMSO. $E_{\mathrm{a}}$ is the activation energy, and $R$ is the gas constant. $T$ is the absolute temperature, and $t$ is the time (duration) of the membrane annealing treatment. 
of the solvent). Finally, the presence of a polar aprotic solvent, such as DMSO, facilitates the charge separation in the transition state, with a positive effect on the reaction. This effect would be in agreement with the hypothesis that the rate-determining step of the cross-linking reaction is the formation of the electrophilic species. Given the similarity in the DS and the number of residual solvent molecules (cf. Table 2), one can assume that DMSO is preferentially located near the sulfonic acid groups, where it can assist the formation process of the electrophile during the crosslinking reaction.

\section{Conclusions}

We have shown that thermal treatments of SPEEK membranes performed above $120^{\circ} \mathrm{C}$ can significantly modify the water-uptake behavior of the membranes. The performed annealing treatments are of important practical relevance, because the water budget is central for the technological viability of membranes either at higher temperature or at low relative humidity.

Thermogravimetry, elemental and titration analysis, and FTIR spectra consistently indicate that SAP microstructure stabilization is related to cross-linking of the polymer chains by $\mathrm{SO}_{2}$ bridges, which is promoted by temperature. A proposed chemical kinetics model is in agreement with this hypothesis. The performed kinetic calculations allow for the prediction of the best thermal treatment conditions for an SAP membrane.

Membranes treated at $160{ }^{\circ} \mathrm{C}$ can resist liquid water at high temperature $\left(100-145^{\circ} \mathrm{C}\right)$. The presence of cross-linking should also decrease the fuel crossover. The whole of these characteristics make thermally treated SAP membranes most interesting for application in DMFCs.

Acknowledgment. The authors thank the Franco-Italian University for a thesis grant (E.S. Vinci program 2006) and the Italian Ministry of University and Research for financial support (NUME project).

\section{References and Notes}

(1) Li, Q.; He, R.; Jensen, J. O.; Bjerrum, N. J. Chem. Mater. 2003, $15,4896$.

(2) Alberti, G.; Casciola, M.; Massinelli, L.; Bauer, B. J. Membr. Sci. 2001, 185, 73 .

(3) Rikukawa, M.; Sanui, K. Prog. Polym. Sci. 2000, 25, 1463.

(4) Sone, Y.; Ekdunge, P.; Simonsson, D. J. Electrochem. Soc. 1996, 143,1254 .

(5) Kreuer, K. D. J. Membr. Sci. 2001, 185, 29.

(6) Swier, S.; Ramani, V.; Fenton, J. M.; Kunz, H. R.; Shaw, M. T.; Weiss, R. A. J. Membr. Sci. 2005, 256, 122.

(7) Kerres, J. A. Fuel Cells 2005, 5, 230.

(8) Di Vona, M. L.; Sgreccia, E.; Licoccia, S.; Khadhraoui, M.; Denoyel, R.; Knauth, P. Chem. Mater. 2008, 20, 4327.

(9) Kobayashi, T.; Rikukawa, M.; Sanui, K.; Ogata, N. Solid State Ionics 1998, 106, 219.

(10) Merdas, I.; Thominette, F.; Tcharkhtchi, A.; Verdu, J. Compos. Sci. Technol. 2002, 62, 487.

(11) Casciola, M.; Alberti, G.; Sganappa, M.; Narducci, R. J. Power Sources 2006, 162, 141.

(12) Alberti, G.; Casciola, M.; Pica, M.; Tarpanelli, T.; Sganappa, M. Fuel Cells 2005, 5, 366.

(13) Adjemian, K. T.; Lee, S. J.; Srinivasan, S.; Benziger, J.; Bocarsly, A. B. J. Electrochem. Soc. 2002, 149, 256.

(14) Antonucci, P. L.; Arricò, A. S.; Creti, P.; Ramunni, E.; Antonucci, V. Solid State Ionics 1999, 125, 431.

(15) Mohanty, D.; Sachdeva, Y.; Hedrik, J.; McGrath, J. J. Am. Chem. Soc. 1984, 25, 19.

(16) Jin, X.; Bishop, M. T.; Ellis, T. S.; Karasz, F. E. Br. Polym. J. $1985,17,4$.

(17) Mark, J. Polyetheretherketones. In Encyclopaedia of Polymer Science and Engineering; May, R., Ed.; J. Wiley \& Sons: New York, 1988; Vol. 13, p 313.
(18) Di Vona, M. L.; Luchetti, L.; Spera, G. P.; Sgreccia, E.; Knauth, P. C. R. Chimie 2008, 11, 1074.

(19) Robertson, G. P.; Mikhailenko, S. D.; Wang, K.; Xing, P.; Guiver, M. D.; Kaliaguine, S. J. Membr. Sci. 2003, 219, 113.

(20) Premchand, Y. D.; Di Vona, M. L.; Knauth, P. Proton-Conducting Nanocomposite and Hybrid Polymers. In Nanocomposites: Ionic Conducting Materials and Structural Spectroscopies; Springer: Boston, 2008; pp 71118.

(21) Di Vona, M. L.; Premchand, Y. D.; Knauth, P. Hybrid and Nanocomposite Materials for Fuel Cells. In Encyclopedia of Nanoscience and Nanotechnology; Nalwa, H. S., Ed.; American Scientific Publishers: Valencia, CA, 2008; in press.

(22) Hickner, M. A.; Ghassemi, H.; Kim, Y. S.; Einsla, R.; McGrath, J. Chem. Rev. 2004, 104, 4587.

(23) Yang, Y.; Holdcraft, S. Fuel Cells 2005, 5, 171.

(24) Sgreccia, E.; Khadhraoui, M.; de Bonis, C.; Licoccia, S.; Di Vona, M. L.; Knauth, P. J. Power Sources 2008, 178, 667.

(25) Di Vona, M. L.; Marani, D.; D'Epifanio, A.; Licoccia, S.; Beurroies, I.; Denoyel, R.; Knauth, P. J. Membr. Sci. 2007, 304, 76.

(26) Di Vona, M. L.; Licoccia, S.; Knauth, P. Solid State Ionics 2008, 179,1161 .

(27) Alberti, G.; Narducci, R.; Sganappa, M. J. Power Sources 2008, 178,575 .

(28) Chen, J.; Maekawa, Y.; Asano, M.; Yoshida, M. Polymer 2007, 48,6002 .

(29) Deb, P. C.; Rajput, L. D.; Hande, V. R.; Sasane, S.; Kumar, A. Polym. Adv. Technol. 2007, 18, 419.

(30) Yen, S. P. S.; Narayanan, S. R.; Halpert, G.; Graham, E.; Yavrouian, A. Polymer material for electrolytic membranes in fuel cells. U.S. Patent $5,795,496,1998$

(31) Rozière, J.; Jones, D. J. Annu. Rev. Mater. Res. 2003, 33, 503.

(32) Zaidi, S. M. J.; Mikhailenko, S. D.; Robertson, G. P.; Guiver, M. D.; Kaliaguine, S. J. Membr. Sci. 2000, 173, 17.

(33) Frisch, M. J.; Trucks, G. W.; Schlegel, H. B.; Scuseria, G. E.; Robb, M. A.; Cheeseman, J. R.; Montgomery, J. A., Jr.; Vreven, T.; Kudin, K. N.; Burant, J. C.; Millam, J. M.; Iyengar, S. S.; Tomasi, J.; Barone, V.; Mennucci, B.; Cossi, M.; Scalmani, G.; Rega, N.; Petersson, G. A.; Nakatsuji, H.; Hada, M.; Ehara, M.; Toyota, K.; Fukuda, R.; Hasegawa, J.; Ishida, M.; Nakajima, T.; Honda, Y.; Kitao, O.; Nakai, H.; Klene, M.; Li, X.; Knox, J. E.; Hratchian, H. P.; Cross, J. B.; Bakken, V.; Adamo, C.; Jaramillo, J.; Gomperts, R.; Stratmann, R. E.; Yazyev, O.; Austin, A. J.; Cammi, R.; Pomelli, C.; Ochterski, J. W.; Ayala, P. Y.; Morokuma, K.; Voth, G. A.; Salvador, P.; Dannenberg, J. J.; Zakrzewski, V. G.; Dapprich, S.; Daniels, A. D.; Strain, M. C.; Farkas, O.; Malick, D. K.; Rabuck, A. D.; Raghavachari, K.; Foresman, J. B.; Ortiz, J. V.; Cui, Q.; Baboul, A. G.; Clifford, S.; Cioslowski, J.; Stefanov, B. B.; Liu, G.; Liashenko, A.; Piskorz, P.; Komaromi, I.; Martin, R. L.; Fox, D. J.; Keith, T.; Al-Laham, M. A.; Peng, C. Y.; Nanayakkara, A.; Challacombe, M.; Gill, P. M. W.; Johnson, B.; Chen, W.; Wong, M. W.; Gonzalez, C.; Pople, J. A. Gaussian 03, revision B.01; Gaussian, Inc.: Pittsburgh, PA, 2004.

(34) Nguyen, H. X.; Ishida, H. Polymer 1986, 27, 1400.

(35) Nguyen, H. X.; Ishida, H. J. Polym. Sci. B: Polym. Phys. 1986, 24,1079

(36) Bellamy, L. J. The Infrared Spectra of Complex Molecules; Chapman and Hall: London, 1980; Vol. 1.

(37) Adzamli, I. K.; Libson, K.; Lydon, J. D.; Elder, R. C.; Deutsch, E. Inorg. Chem. 1979, 18, 303.

(38) Di Vona, M. L.; Marani, D.; D’Ottavi, C.; Trombetta, M.; Traversa, E.; Beurroies, I.; Knauth, P.; Licoccia, S. Chem. Mater. 2006, 18, 69.

(39) Zook, L. A.; Leddy, J. Nafion-Cold Cast, Thermally Processed and Commercial Films: Comparison of Density, Water Content, and Equivalent Weight. In New Directions in Electroanalytical Chemistry II; Leddy, J., Vanysek, P., Porter, M. D., Eds.; The Electrochemical Society: Pennington, NJ, 1999; Vol. 99-5, pp 217-225.

(40) Marani, D.; Di Vona, M. L.; Traversa, E.; Licoccia, S.; Beurroies, I.; Llewellyn, P. L.; Knauth, P. J. Phys. Chem. B 2006, 110, 1581.

(41) Guan, R.; Zou, H.; Lu, D.; Gong, C.; Liu, Y. E. Polym. J. 2005, 41,1554 .

(42) Olah, G. A.; Matew, T.; Surya Prakash, G. K. Chem. Commun. 2001, 1696.

(43) Atomic charges are not quantum mechanical observables, and methods for their calculation are necessarily arbitrary. Therefore, it is not the absolute values obtained that should be considered, but only their variation within the model.

(44) Benson, S. W. The Foundations of Chemical Kinetics; McGrawHill: New York, 1960.

(45) Huang, R. Y. M.; Shao, P.; Burns, C. M.; Feng, X. J. Appl. Polym. Sci. 2001, 82, 2651.

(46) Mikhailenko, S. D.; Wang, K.; Kaliaguine, S.; Xing, P.; Robertson, G. P.; Guiver, M. D. J. Membr. Sci. 2004, 233, 93.

\section{JP9006679}

